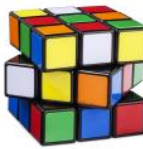

Лідер. Еліта.Суспільство

Leader. Elite. Society

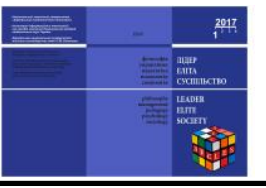

УДК 37.04:340.6

doi: 10.20998/2616-3241.2018.1.10

\title{
Алла Семенова
}

доктор педагогічних наук, професор, кафедра політології, Одеський національний політехнічний університет, Одеса, Україна ORCID: 0000-0001-8077-3385

E-mail:semenova.alla.vasilivna@gmail.com

\section{ПОСТНЕКЛАСИЧНИЙ ПЕРІОД МЕТОДОЛОГІЧНОГО ВИМІРУ ЄДНОСТІ НЕЛІНІЙНОГО СИНТЕЗУ ЗНАНЬ В АСПЕКТІ РОЗВИТКУ ТЕОРІЙ ЛІДЕРСТВА}

\begin{abstract}
Анотація: Розглянуто сутність постнекласичного періоду методологічного виміру єдності нелінійного синтезу знань в аспекті розвитку теорій лідерства. Схарактеризовано особливості нелінійних процесів самоорганізаиії. Розкрито тенезу теорій лідерства у иілісному аспекті та з позицій нелінійного синтезу знань у постнекласичний період. Здійснено аналіз стану дослідження проблеми підготовки нової генераиії науково-педагогічних та інженерно-педагогічних кадрів - начіональної еліти, яка здатна оволодіти новою постнекласичною методологічною освітньо-світоглядною парадигмою. Доведено важливість моделювання міждисциилінарної комунікації, філософської рефлексії та колективної експертизи на прикладі курсів підвищення педагогічної та управлінської кваліфікації науково-педагогічних кадрів.
\end{abstract}

Ключові слова: нелінійний синтез знань, теорії лідерства, самоорганізація наукових спільнот, педагогічна майстерність викладача вищої школи, підвищення кваліфікації науково-педагогічних кадрів.

Alla Semenova

Full Professor of Department of Political Science of The Odessa National Polytechnic University, Doctor of sciences (Pedagogical), Odessa, Ukraine E-mail: semenova.alla.vasilivna@gmail.com

\section{POST-MODERN PERIOD OF METHODOLOGICAL PARAMETERS OF UNITY OF NON-LINEAR KNOWLEDGE SYNTHESIS IN THE ASPECT OF THE DEVELOPMENT OF LEADERSHIP THEORIES}

Abstract: The essence of the post-modern period of methodological parameters of the unity of non-linear synthesis of knowledge in the aspect of the development of leadership theories is considered. Characteristics of nonlinear processes of self-organization are characterized. The genesis of the theory of leadership in a holistic aspect and from the point of view of non-linear synthesis of knowledge in the post-modern period is revealed. The analysis of the research of the problem of preparation of a new generation of scientific pedagogical and engineering pedagogical cadres, the national elite, capable of mastering the

(c) Алла Семенова, 2018 
new post-modern methodological educational-worldview paradigm is carried out. The importance of modeling interdisciplinary communication, philosophical reflection and collective expertise on the example of courses for improving pedagogical and managerial qualifications of scientific and pedagogical personnel is proved.

Key words: nonlinear synthesis of knowledge, theory of leadership, self-organization of scientific communities, pedagogical skills of a teacher of higher education, advanced training of scientific and pedagogical staff.

\section{Alla Semenova \\ An extended abstract of a paper on the subject of: \\ "Post-modern period of methodological parameters of unity of non-linear knowledge synthesis in the aspect of the development of leadership theories"}

Problem setting. Natural and social human life, and also environment, as a functioning ecosystem, is complex non-linear processes of self-organization. On some stages these processes create new complex systems, while on the others - immerse them in the chaotic state. The study of the complex systems, which are able to self-organize, is the subject of modern post-non-classical science. During global informational revolutions, the whole system of foundations of the science, such as: norms of scientific research; methodological principles, that regulate the application of new methods; a scientific picture of the world that represents the subject of research; philosophical foundations that justify the methodology and ontology; is rebuilt. Currently take places the discussions about the correlation between science and art, science and ethics, morality, humanism. The key idea here is the priority attention to preparation of a new generation of scientific-pedagogical and engineeringpedagogical staff, who is able to master the new post-non-classical educationalideological paradigm of national-state creation, the humane elevation of the selfsufficient personality of a future specialist.

Recent research and publications analysis. The formation of real systems under certain conditions, with the choice of one of the possible variants of self-organization, is the subject of non-linear science. For nonlinear synthesis of knowledge, fundamentalism of the previous stages is unsuitable. As the choice of options for self-organization has fundamentally random character. It can be determined by the external conscious or involuntary influence of a person on a selforganizing system. This circumstance is the basis of human freedom and its associated risks. At an active age, adults can influence on the historical events, guided by the values at which they were formed as individuals. The subject structure of knowledge does not allow specifying a single approach to the solution of complex problems that related to the activities of the systems of the highest level of organization: personality, education, society. The essence of the theory of leadership lies in the fact that followers recognize the leader only when he proved his competence and value for them. Interpretation of the phenomenon of leadership has been reflected in many theories: situational, functional, behavioral, and others, and also integral theory of leadership. Particular importance of the post-non-classical period in the aspect of the development of theories of leadership is the ideas of the formation of managerial competencies, as the ability to act in situations of uncertainty. The methodological advantage of synergetic lies in the fact that it offers a fundamentally new approach to forecasting. This approach is based not only on the analysis of the current situation and direct development trends, but also on the understanding of individual goals - attractor structures. The realization of the unity of the nonlinear knowledge synthesis in the aspect of the development of leadership theories on the basis of the synergistic approach will allow the 
head of any level to build around one common path a plurality of lateral paths (educational development paths) that will demonstrate the nature of the probability of processes, the variety of possibilities of ways to increase the efficiency of the functioning of systems and methods of managing them.

Paper objective. To reveal the essence and features of the post-non-classical period of the methodological measurement of the unity of the nonlinear synthesis of knowledge in the aspect of the development of theories of leadership.

Paper main body. Management competencies, which are manifested in human behavior, turn into its personal qualities and properties. These competences are characterized by motivational, semantic, regulatory components, along with knowledge and experience. It creates the basis for a conscious choice of human actions, the additional advantage of which is the relatively small energy, that required for the corresponding impacts at the points of bifurcation. Nonlinear systems at these points are fundamentally open and extremely sensitive. Consequently, consideration of the theoretical reconstruction of nonlinear phenomena makes sense in the broad context of scientific discourse. In favor of this approach is evidenced the growth of the significance of scientific communication within the framework of interdisciplinary projects, which are typical for complex problems of nonlinear science in the study of complex human-dimensional systems: pedagogical, ecological, technological, etc., is evidenced. A study of real practice can be considered from the point of view of self-organization in the field of scientific communication, especially when it comes to multidisciplinary scientific communities. Currently, there is a self-organization of scientific communities. Among the methodological models of science, the models of the growth of knowledge as changes in theories are not at the forefront, while models of the historical school in the methodology of science are. I.A. Zyazyun's scientificpedagogical school represents a socially- formed community of people, which creates a real-ideal space of their culture. At the same time, the form of the community of representatives of different generations, of various professional forms of activity also creates a space of real-ideal culture. An educational space combines all individuals in a common activity and ensures the existence of this community. The primary qualities of the teacher are the intellectual competence, initiative, creativity, self-regulation, uniqueness of the ethical and aesthetic development of the subjects of the educational process. In October 2013, the Educational-Consultative Center for Pedagogical Excellence (NCCPM) was established in Odessa $\mathrm{Na}$ tional Polytechnic University in order to increase the pedagogical and managerial qualifications of scientific and pedagogical staff, creating conditions for the formation, development and self-development of pedagogical skills. Estimation of the dynamics of development of pedagogical mastery of teachers allowed to specify the stages of successful change of attitudes towards the development of valuable experience from teachers of all ages: 1. Inaccuracy; 2. Considerations; 3. Preparation; 4. Action. Seminar programs for teachers with different backgrounds and ages provide opportunities for practicing enrichment of valuable experiences, exchanging views and attitudes, understanding with other generations and self-knowledge. The specifics of the courses are in practical orientation and the creation of possibilities for modeling the real pedagogical process. The novelty of the approaches is connected with the holistic use of the key ideas of the synergetic of education, psycho-pedagogy as an integrative science about the epistemological principles of the professional activity of the teacher-master.

Conclusions of the research. In the context of the modernization of higher education in Ukraine, priority attention should be given to the preparation of a new generation of scientific-pedagogical and engineeringpedagogical personnel - the national elite. Relying on the constructive experience of the 
Ukrainian scientific school of I.A. Zyazyun, it became possible to define the general theoretical and methodological sources and the content lines of the post-non-classical period

Постановка проблеми в загальному вигляді та їі зв'язок із важливими науковими чи практичними завданнями. «Світ, мабуть, завжди був складним, та науці Нового часу більше трьохсот років поспіль удавалось успішно його спрощувати, зокрема, лінеаріазувати нелінійні ситуації. Так, наприклад, в астрофізиці рух планет навколо Сонця розглядався як механічний рух двох тіл, пов’язаних гравітацією, тому що ситуація взаємодії навіть трьох тіл уже $\epsilon$ нелінійною. Наявність інших планет у Сонячній системі враховувалась як збурення руху, електромагнітною взаємодією нехтували. Такий спрощений підхід продовжує працювати в різних галузях науки і техніки. Але наразі ми живемо в епоху, коли в багатьох випадках нелінійність та складність світу вже не можуть ігноруватись. I це не тільки смерчі та цунамі, техногенні катастрофи і революційні збурення в соціумі - події, яким не можна зарадити, але про які можна попередити. Власне, саме людське життя, природне і соціальне, а також довкілля, зрозуміле як екосистема, є складними нелінійними процесами самоорганізації, що на одних етапах породжують нові складні системи, а на інших етапах занурюють їх у хаотичний стан. Вивчення таких складних систем, здатних до самоорганізації, стало предметом сучасної постнекласичної науки. Науковці й освітяни, які нею займаються, здійснюють і переживають перебудову своєї діяльності та ії усвідомлення» - пише президент Українського Синергетичного товариства - I.C. Добронравова, д.філос.н., проф., завідувач кафедри філософії і методології науки Київського національного університету імені Тараса Шевченка [4, с. 179]. Під час глобальних інформаційних революцій перебудовується вся система засад науки: норми наукового дослідження; методологіч- of the methodological measurement of the unity of the nonlinear synthesis of knowledge in the aspect of the development of theories of leadership.

ні принципи, які регулюють застосування нових методів; наукова картина світу, яка репрезентує предмет досліджень; філософські засади, що обгрунтовують методологію та онтологію.

Нині мають місце дискусії про співвідношення науки і мистецтва, науки і етики, моральності, гуманізму. Натомість ідеали наукового дослідження Нового часу мають залишатися незмінними: це новизна знання та його об'єктивна істинність. Але сьогодні, як ніколи раніше зрозуміло, що наука і освіта, які не освячені високою етичною, гуманістичною метою Істини, Добра та Краси, загрожують загибеллю культури, цивілізації. Наука й Освіта за своєю природою і місією мають бути віддзеркаленням реалізації гуманізму, водночас як і гуманізм $є$ умовою справжнього їхнього розквіту $[20$, с. 6]. Ключовою ідеєю методологічного виміру єдності нелінійного синтезу знань в аспекті розвитку теорій лідерства $\epsilon$ те, що серед усього іншого система освіти має бути «виключно опочуттевленою діяльністю планування майбутнього світу людства» $[8$, c. 431]. В умовах модернізації вищої освіти в Україні пріоритетна увага має надаватися підготовці нової генерації науковопедагогічних та інженерно-педагогічних кадрів - національної еліти, яка здатна оволодіти новою постнекласичною методологічною освітньо-світоглядною парадигмою національно-державного творення, гуманного піднесення самоцільної особистості майбутнього фахівця.

Аналіз останніх досліджень і публікацій, у яких започатковано розв'язання цієї проблеми і на які спирається автор. В одних випадках для збагачення онтологічної та епістемологічної підсистем філософської системи засад науки і освіти досить звернутися до скарбниці філософської спадщини. В інших - ця скарбниця має 
поповнитися новими філософськими винаходами. У будь-якому разі йдеться про філософсько-методологічну рефлексію над науково-освітніми проблемами та здобутками. Коли адекватні філософські засади винайдено, методологія набуває статусу наукової свідомості [11, с. 567584]. Закони, що вивчає лінійна наука, лінійні. Вони є інваріантами щодо зміни знаку часового виміру та утворюють незмінну сутність явищ, які досліджуються класичною та некласичною наукою. Отже, епістемологічно пошук істини асоціювався 3 відкриттям таких законів. А методологічна сторона полягала у тому, що дослідження явищ жодним чином не зачіпало їх сутність, тому повторюваність спостережуваних феноменів вважалась основою відкриття регулярностей, які складали зміст емпіричних залежностей.

Фундаменталізм, в основу якого покладено те, що головне зрозуміти як світ працює в принципі, а все інше - справа техніки, і досі саме так сприймається багатьма науковцями, особливо тими, хто працює в галузі застосування лінійних теорій. Але й у лінійній науці намагання побудувати так звані прикладні теорії на основі фундаментальних зовсім не є суто технічною справою. Протиставлення незмінної сутності змінним явищам, абстрагування від конкретних умов реального існування - це основа ідеалізацій, які визначають і успіхи лінійної науки, і ії обмеженість. Становлення конкретних систем у певних умовах у всій повноті їх існування, з вибором сутності, що постає в одному з можливих варіантів самоорганізації, - це вже предмет нелінійної науки, для якої фундаменталізм попередніх етапів є неприйнятним [4, с. 181]. Ось як характеризують таку непридатність Х.О. Пайтген та П.Х. Ріхтер, автори відомої книги «Краса фракталів»: «Будь-який нелінійний процес призводить до розгалуження, до розгілля, у якому система може обрати той або інший шлях. Ми маємо справу 3 вибором і прийняттям рішень, наслідки яких неможливо передбачити, оскільки для кожного з цих рішень $є$ характерним невизначеність. Рано чи пізно початкова інформація про стан системи перестає бути корисною. У ході еволюції будь-якого процесу інформація генерується і запам'ятовується. Закони природи допускають для подій множину різних варіантів, але наш світ має одну-єдину історію» $[15$, с. 17]. Важливо зауважити, що вибір варіантів самоорганізації має принципово випадковий характер. Він може визначатись зовнішнім впливом на систему, що самоорганізується, зокрема свідомим або мимовільним впливом людини. Ця обставина є основою людської свободи і пов'язаних з нею ризиків. Уникнення дії не означає, що вибір системою не буде зроблено на грунті внутрішнього або зовнішнього «шуму».

Зміна цінностей суспільства відбувається постійно: змінюються пріоритети та ієрархія, знецінюються одні і висуваються інші. На думку І.А. Зязюна, педагогічна дія, що спрямовується на розвиток особистості, стає можливою тоді, коли вона грунтується на одвічних загальнолюдських духовних цінностях: «...необхідна побудова цілісного процесу набування знань, адекватних життю, побудова органічного комплексу гуманітарно-соціально-історичних, природничонаукових i художніх дисциплін, об'єднаних єдністю гуманістичних смислів і духовно-моральних цілей» [7, с. 215]. В активному віці дорослі люди можуть впливати на історичні події, керуючись тими цінностями, на яких вони сформувалися як особистості. 3 таких позицій автор цієї статті вже пояснювала сутність теорії лідерства [18], яка полягає в тому, що послідовники визнають лідера тільки в тому випадку, коли він довів свою компетентність і цінність для них.

Ідеальним варіантом уважається поєднання формального і неформального лідерства, тобто офіційний керівник визнається членами групи і як лідер [19]. У тих випадках, коли керівник і лідер не збігаються в одній особі можуть виникати 
незадоволеність роботою та збільшення конфліктності. Лідерство - процес соціального впливу, завдяки якому лідер отримує підтримку з боку інших членів спільноти для досягнення мети [21]. Витлумачення феномену лідерства знайшло відображення у багатьох теоріях: ситуаційній, функціональній, поведінковій та інших, а також інтегральній теорії лідерства [19]. Питаннями про те, що відрізняє лідерів від пересічних людей, цікавилися ще філософи від Платона до Плутарха, тим самим стверджуючи, що витоки лідерства полягають в індивідуальних особливостях людини. У XIX столітті лідера протиставляли натовпу, рабам і намагалися знайти цьому пояснення. Одну з найбільш впливових теорій того часу сформулював Френсіс Гальтон [1], який вважав лідерство проявом природного, спадкового таланту. Сесіль Родс [22], у свою чергу, переконував, що лідера можна виховати з обдарованої людини шляхом відповідного навчання. У 20-х роках XX століття, коли щойно почав з'являтися інтерес до управління як до науки, перше, на що звернули увагу дослідники, це на можливу наявність схожих рис характеру різних відомих лідерів. Так з'явилася «Теорія рис» або «Теорія великих людей». Але виявилося, що конкретизувати загальні риси дуже складно - створити загальний портрет лідера не вдалося. У 1940-х-1950-х роках численні оцінки раніше сформульованих теорій привели до висновку про необхідність розробки нового підходу до вивчення проблеми лідерства. Так 3'явилася ситуаційна теорія лідерства, згідно $з$ якою поява лідера зумовлюється ситуацією, що склалася. Третій крок дослідників - системна теорія лідерства. Тут лідерство і лідер розглядаються з точки зору групової динаміки [12]. Особливої значущості постнекласичного періоду методологічного виміру єдності нелінійного синтезу знань в аспекті розвитку теорій лідерства мають ідеї формування управлінських компетентностей, як здатностей діяти в ситуаціях невизначеності.
Виділення не вирішених раніше частин загальної проблеми, котрим присвячується дана стаття. Останнім часом все більш інтенсивно обговорюються ідеї діалогу, співпраці, сумісної дії, необхідності розуміння чужої точки зору, пошани особистості, прогнозування іiї розвитку. Ці ідеї й визначають інтенсивний розвиток нових підходів, які ще більш гостро окреслили проблему методологічної кризи в освіті, науці, економіці, політиці. У XX столітті відбулося багато важливих змін у методології пізнання. Було усвідомлено, що предметна структура знання, яка склалася, не дозволяє конкретизувати єдиний підхід до вирішення комплексних завдань, що стосуються діяльності систем найвищого рівня організації: особистості, освіти, суспільства. Так з'явилися ідеї синергетики, теоретичної кібернетики, поліпарадигмальності та ін. Нагальна необхідність таких (гуманних, орієнтованих на людину) теорій в сучасній економіці, управлінні, освіті та інших сферах визначається тим, що ще в XX столітті людство потрапило в область нестійкості розвитку (що триває по нині), коли незначні, здавалося б, вчинки, дії окремих осіб стали призводити до катастрофічних для суспільства наслідків. Тому наразі принципово важливою $є$ розробка вчення про людиномірні стратегії поведінки, які дозволили б уникнути небезпечних для суспільства наслідків в інформаційному середовищі.

Методологічна перевага синергетики полягає у тім, що іiї предмет охоплює всю цілісність універсального процесу самоорганізації як етапів розвитку відкритої системи - виникнення, зміни, самоускладнення в аспекті структурного впорядкування. Іншими словами, синергетична парадигма є найбільш повною, трансдисциплінарною науково-методологічною теорією. Адже: «саме на перетині моделювання міждисциплінарної комунікації, філософської рефлексії та колективної експертизи виникає синергетична методологія» [2]. Оскільки таке моделювання асоціюється з соціальною самоорганізацією, 
а загальна теорія соціальної самоорганізації тісно пов'язана з синергетичною філософією, то для кваліфікованого пояснення особливості постнекласичного періоду методологічного виміру єдності нелінійного синтезу знань необхідним є пояснення сутності синергетичного підходу, адже сьогодні теза про досягнення рівноваги є занадто вузькою [5]. Окрім того, існує така поведінка, яку можна зрозуміти тільки у термінах теорії хаосу [6].

Фундатор «Педагогічної майстерності» академік I. А. Зязюн зауважував, що: «через синергетику можна досягти більш глибокого розуміння найрізноманітніших явищ природи і світу людини. Цілком можливе прикладання синергетики до розуміння складних феноменів психіки і креативності людини. Вона стане в нагоді для зняття деяких психологічних бар'єрів, зокрема страху перед складними системами, страху перед хаосом, допоможе побачити і відчути красу і подвійність природи, конструктивність і деструктивність хаосу. Синергетика - це устремління людини в глибини матеріального і духовного світу, шлях до пізнання глибинних пластів Всесвіту»[8]. Автор статті, продовжуючи розвивати ідеї І.А. Зязюна, переконана, що синергетика пропонує принииипово новий підхід до прогнозування, який грунтується не тільки на аналізі наявної ситуації і безпосередніх тенденцій іiі розвитку, а також на розумінні окремих цілей розвитку, тобто структур-аттракторів еволюції складних систем [20]. Реалізація єдності нелінійного синтезу знань в аспекті розвитку теорій лідерства на підгрунті синергетичного підходу дозволить керівнику будь-якого рівня вибудовувати навколо однієї загальної ще багато бокових траєкторій (освітніх маршрутів розвитку), що дозволить показати характер вірогідності процесів, різноманіття можливостей шляхів підвищення ефективності функціонування систем і способів управління ними [19].

Формулювання цілей статті. Розкрити сутність і особливості постнекласичного періоду методологічного виміру єд- ності нелінійного синтезу знань в аспекті розвитку теорій лідерства.

Виклад основного матеріалу дослідження 3 повним обгрунтуванням отриманих наукових результатів. Поперше пояснимо якими епістемологічними засадами може бути забезпечене зростання методології нелінійної науки до методологічної свідомості постнекласичного типу наукової раціональності. Управлінські компетентності, виявляючись у поведінці людини, перетворюються у її особистісні якості, властивості та, відповідно, стають компетентностями, які характеризуються і мотиваційними, і смисловими, i регуляторними складовими поряд зі знаннями та досвідом. Відтак, теоретична реконструкція нелінійних ситуацій на грунті нелінійних законів має переваги при побудові, наприклад, графіків розв'язань відповідних нелінійних рівнянь, що мають розгалуження. Точки, у яких відбувається розгалуження, зокрема роздвоєння - точки біфуркації, можуть бути розглянуті як точки формування дієвих причин. Нелінійна динаміка, що розгортається після проходження цих особливих точок, характеризується необхідністю, але це реальна необхідність, яка містить у собі випадковість вибору одного 3 можливих варіантів перебігу подій. Саме це і створює підстави свідомого вибору людських дій, додатковою перевагою яких $\epsilon$ порівняно невелика енергія, потрібна для відповідних впливів у точках біфуркації, бо нелінійні системи в них принципово відкриті, тобто надзвичайно чутливі [4, с. 183]. Це означає, що теоретична реконструкція подається нелінійними теоріями у вигляді альтернативних варіантів перебігу нелінійної динаміки.

Реалізація одного з варіантів за певних, випадкових або спеціально створюваних умов не означає, що нереалізований варіант, передбачений теорією як альтернатива реалізованому, не може розглядатися як наукова істина. Отже, теоретичне усвідомлення можливих альтернатив перебігу подій створює підгрунтя для людської свободи, особливо якщо відомі умо- 
ви реалізації сприятливої або уникнення небезпечної альтернативи. Звичайно, така свобода не є необмеженою, і не тільки тому, що потрібні умови людина не завжди спроможна створити [3]. Теоретичне пояснення певного стану нелінійної системи $\epsilon$ описом конкретного перебігу подій у розгортанні їі нелінійної динаміки. Адже, крім знання законів, потрібно знати ще який конкретний вибір здійснює в особливих точках уся система (чи групи іiі елементів), когерентний рух яких до певного аттрактору і $є$ самоорганізацією нового складного цілого, що характеризується параметром порядку. Цілісність систем, що самоорганізуються, робить неприйнятним методологічний принцип редукції, який зводив пояснення системи до знання про її елементи та взаємодії між ними. Спільна доля цих елементів в умовах нелінійності - це доля утворюваного ними цілого, це визначальна роль цілісності, складність нового цілого, яке в жодному разі не $\epsilon$ сумою окремих елементів.

Усвідомлення наявних альтернатив перебігу подій пов'язане 3 теоретичним відтворенням набору потенційних можливостей, $з$ виявом набору аттракторів, що $\epsilon$ характерними для нелінійного стану певного середовища та можуть трактуватися як цільові причини, принаймні до входження системи в стан динамічного хаосу [4, с. 185]. Отже, розгляд теоретичної реконструкції нелінійних феноменів має сенс проводити в широкому контексті наукового дискурсу. На користь цього підходу свідчить і зростання значення наукової комунікації в межах міждисциплінарних проектів, типових для комплексних задач нелінійної науки при дослідженні складних людиновимірних систем: педагогічних, екологічних, технологічних, медико-біологічних та ін. Цей підхід орієнтований не на формулювання норм, які мають регулювати процеси дослідження, а на опис реальних практик науки.

Одним із перших поступів у такому підході була розробка концепції наукових парадигм Т. Куна. Вона знаменувала со- бою відмову від пошуків універсальної методології і визнавала різноманітність методологічних настанов у різних парадигмах: зміст поняття визначає його межі. Якщо ж зважити на те, що зміст поняття ще асоціювався з суб'єктом, що його визначив, то значення термінів різних теорій чи парадигм повністю позначалося відповідним теоретичним контекстом. Такого релятивізму уникла концепція історичних типів наукової раціональності, створена академіком В. С. Стьопіним, оскільки вона із самого початку спиралась на іншу традицію - традицію діяльнісного підходу до науки, що базувався на врахуванні практичної діяльності, зануреної в історичний культурний контекст. Автор цієї статті свого часу (2009) захистила дисертаційне дослідження на здобуття наукового ступеня доктора педагогічних (наук. консультант - доктор філософських наук, професор, дійсний член АПН України I. А. Зязюн) на тему «Теоретичні та методичні засади парадигмального моделювання у професійній підготовці майбутніх учителів», серед іншого дослідивши, що на вивчення реальної практики науки спрямовані і так звані casestudies.

До вивчення такої реальної практики спрямований і соціологічний напрям у філософії науки, зокрема підходи, що вивчають науку у зв'язку з технологіями та соціальною зумовленістю іiі розвитку [9, с. 642-663]. Соціологічний підхід є одним 3 варіантів натуралізованої епістемології. Іншим напрямом натуралізованої епістемології є еволюційна епістемологія, яка виступає епістемологічним підгрунтям сучасних когнітивних досліджень. Когнітивістика пов'язана з апеляцією до єдності природничих та гуманітарних досліджень щодо засад когнітивних здатностей людини, до нейрофізіології, нейропсихології, нейролінгвістики та навіть нейроекономіки. Еволюційна епістемологія користується синергетичними образами, розглядаючи ідею як аттрактор у середовищі наукового знання [14]. Погляд еволюційної епістемології у цьому випадку базу- 
ється на абстрагуванні від конкретних суб'єктів пізнання. Але утворення нового постнекласичного знання може бути розглянуто з точки зору самоорганізації у середовищі наукової комунікащії, особливо коли йдеться про полідисциплінарні наукові співтовариства, які складаються 3 метою розв'язати складні комплексні проблеми. Тут ми виходимо на такий аспект феномену науки, як існування її як соціального інституту [4, с. 188]. Взагалі, у нелінійній науці стає неможливим «розведення» адекватних аспектів іiі існування, як знання і діяльність щодо його отримання, яке також працює на розширення контексту розгляду наукового розвитку.

Серед методологічних моделей науки на перший план виходять не моделі росту знання як зміни теорій, а моделі $i c$ торичної школи в методології науки. Тут «...варто говорити про науковопедагогічну школу академіка Івана Андрійовича Зязюна, оскільки вона представляє соціально оформлену спільноту людей, що творить реально-ідеальний простір своєї культури - головну умову їхнього життя. Водночас і форма спільноти представників різних поколінь та професійних форм діяльності так само творить простір реально-ідеальної культури, у цьому випадку - освітній простір, який поєднує всіх суб'єктів діяльності у спільній справі, що забезпечує існування цієї спільноти. Ідеї І. А. Зязюна в контексті інноваційності, як тенденції сучасного розвитку освіти, враховують інтелектуальну, емоційну та вольову сфери людини. Ключовими якостями педагога у цьому процесі постають інтелектуальна компетентність, ініціатива, творчість, саморегуляція, унікальність етико-естетичного розвитку суб'єктів освітнього процесу» [10, с. 17]. Сама «Теорія педагогічної майстерності» I.А. Зязюна не має аналогів у світі, їі інноваційність, педагогічна ефективність та вагомість результатів впровадження зумовили їі швидке поширення у вітчизняній і зарубіжній педагогічній освіті (Білорусь, Канада, Китай, Польща, Франція, Японія,
Росія та інші країни) [20]. Педагогічна майстерність $\epsilon$ привабливою й центральною ідеєю для сучасної української педагогіки серед тих науковців, хто прагне й зберігає надію на розквіт Української Науки і Освіти, де Педагогіка Істини, Добра і Краси пануватиме в усіх складниках українського державотворення, зокрема економічному, політичному, ідеологічному, культурному, що зумовлює Освіту і Виховання молоді.

У центрі ідей соратників і учнів академіка Івана Андрійовича Зязюна знаходяться не тільки певні припущення про природу досліджуваних явищ, а також методологічні прийоми позитивної евристики, основи розв'язання проблеми взаємозв'язку психології научіння, дидактики предметних методик і практики підвищення кваліфікації фахівців, шляхи пошуку та подальшого саморозвитку педагогів тощо. Справа у тому, що філософія «Педагогіки добра» I.А. Зязюна дозволяе знаходити відповіді на питання про практичне використання досягнень психологічних теорій розвитку особистості, психопедагогіки, сучасної нейропсихології, аксіології та акмеології у педагогічній практиці. Синегретика, 3 точки зору I.А. Зязюна, виступає як загальнонаукова трансдисциплінарна дослідницька методологія, де вихідні людиномірні ідеї та їх парадигмальні моделі знаходяться у імперативі життєдіяльності людини. У такому аспекті, педагогічна дія, що спрямовується на розвиток особистості, стає можливою тоді, коли вона грунтується на одвічних загальнолюдських духовних цінностях: «...необхідна побудова цілісного процесу набування знань, адекватних життю, побудова органічного комплексу гуманітарно-соціально-історичних, природничонаукових i художніх дисциплін, об'єднаних єдністю гуманістичних смислів і духовно-моральних цілей» [7, С. 215]. Однією 3 передумов вирішення цього надзвичайно важливого і складного завдання є опанування викладачами вищої (особливо технічної) школи грунтовними 
психолого-педагогічними

знаннями,

уміннями, навичками, ставленнями.

Свого часу М. К. Мамардашвілі [13]

відзначив наявність постійної та неуникної напруги між існуванням науки як дослідницької діяльності та як феномену культури. Справа в тому, що наука як культура відтворює своїх носіїв, навчання наступного покоління вчених відбувається на підгрунті вже досягнутих результатів, дослідницька ж діяльність спрямована на отримання нового знання. Існує напруга і між дослідницькою діяльністю та соціальними інститутами, спеціально організованими, щоб ії здійснювати. Ця напруга особливо добре відчувається вченими, які працюють на стрижні науки, коли у своїх заявках на гранти вони намагаються втиснути нову тематику своїх досліджень у прокрустове ложе переліків наукових дисциплін. У постнекласичній науці, яка вивчає складні людиновимірні системи і користується трансдисциплінарними методологіями, це виражено особливо чітко. Ця суперечність між новітністю дослідницької діяльності та сталістю інституціоналізованої науки існувала і на більш ранніх етапах наукового розвитку. Тому при всій організованості наукових інститутів у дисциплінах і навіть квазідисциплінах міждисциплінарного штибу (на кшталт біофізики, фізичної хімії і т. ін.) самоорганізація наукового співтовариства завжди доповнювала цю організацію [4, с. 189].

Таку самоорганізацію наукових спільнот ми спостерігаємо і в процесі сучасної наукової революції та навіть беремо в ній участь. 3 метою підвищення педагогічної та управлінської кваліфікації науково-педагогічних кадрів, створення умов для становлення, розвитку і саморозвитку педагогічної майстерності фахівців, реалізації їхнього інтелектуального потенціалу у сфері наукової та освітньої діяльності в Одеському національному політехнічному університеті у жовтні 2013 року, як структурний підрозділ ОНПУ, створено навчально-консультаційний центр педагогічної майстерності (НКЦПМ), директором НКЦПМ призначено ученицю І.А. Зязюна, доктора педагогічних наук, професора, професора кафедри політології Семенову Аллу Василівну.

Специфіка курсів «Педагогічна майстерність викладача вищої школи» у їхній практичній спрямованості, створенні можливостей моделювання реального педагогічного процесу в стінах ВН3, у залученні викладачів до цього процесу як суб'єктів, що оволодівають прийомами організації власної педагогічної діяльності й аналізують шляхи професійного саморозвитку. Своєрідність курсів «Педагогічна майстерність викладача вищої школи» у принципах їхньої організації: це - диференціація педагогічної діяльності на мікроситуації, які входять до складу певної моделі професійної діяльності (розповідь викладача, індивідуальна бесіда, різних етапи лекцій/семінарів), що дає змогу організувати систему вправ на усвідомлення викладачами власних стратегій поведінки у визначеному контексті. Принцип інтенсивної комунікації забезпечує вияв активності педагогів у взаємодії з аудиторією. Реалізація принципу постійної рефлексії досягається зворотним зв'язком через аналіз кожним викладачем, зокрема і групою у цілому, реальних результатів, яких досягає педагог на курсах. Програма «Педагогічна майстерність викладача вищої школи» зберігає основні концептуальні положення, викладені у програмах та підручниках «Педагогічна майстерність» I. А. Зязюна [16]. Серед основних завдань курсів: «розвити у викладачів здібності щодо визначення найбільш продуктивних прийомів, форм, методів, засобів і цілісних психолого-педагогічних технологій управління і самоуправління з метою підвищення продуктивності науковопрофесійної педагогічної діяльності». Новизна підходів пов'язана із цілісним використанням ключових ідей синергетики освіти, психопедагогіки як інтегративної науки про гносеологічні засади професійної діяльності педагога-майстра щодо гармонійного розвитку особистості майбутнього інженера. Своєчасними, на нашу 
думку, є такі теми як: «Правові засади професійної освіти. Законодавство України про освіту» (навчальні питання: академічна доброчесність як духовнорефлексивне ядро професійної освіти. Стаття 42 Закону України «Про освіту». Принцип «чесного самопрояву» - підгрунтя розвитку ціннісного досвіду суб'єктів педагогічної дії, тощо).

Протягом багаторічного дослідження автора [20] щодо оцінювання динаміки розвитку ціннісного досвіду педагогічної майстерності викладачів вищих навчальних закладів, у період проведення занять 3 підвищення кваліфікації у навчально-консультаційному центрі ОНПУ «Педагогічна майстерність викладача вищої школи», стало можливим виявити та конкретизувати етапи успішної зміни ставлення та поведінки щодо розвитку ціннісного досвіду викладачів різного віку: 1. Непомітність; 2. Міркування; 3. Підготовка; 4. Дія [17]. У цілому, основні глибинні настановлення та изінності особистості, що пов'язані з ними, змінити складніше, ніж буденні звички. Окрім того, має велике значення відправна поведінка людини, система іiі ціннісних орієнтацій, належність до відповідного покоління. У викладачів, які вже відрізнялися досить розвинутим умінням співпереживати, научіння створенню зворотного зв'язку щодо якості власної роботи чи налаштування себе на потреби студентів відбувалося досить легко, оскільки проявлялися здібності, які вже були сформованими.

Програми семінарів з розвитку педагогічної майстерності для викладачів 3 різним досвідом роботи та викладачів різного віку надають можливості практикуватися у збагаченні ціннісного досвіду, обміном поглядами та ставленнями, порозумінню 3 представниками інших поколінь та самопізнанню за допомогою чітко сфокусованих імітаційних ігор, ситуацій. Вони $є$ цілковитим початком підвищення розвитку педагогічної майстерності. Такі заняття можна розглядати як варіант груп «емпатійного професійного спілкування викладачів» у режимі реального часу [17]. Динамічна комунікативна активність самоорганізованих наукових спільнот сприяє ще одній формі самоорганізації знання - це так звані «мозкові штурми», коли у безпосередньому спілкуванні учасників обговорення конкретних наукових проблем народжується їхнє рішення, виникають ідеї, які не можна приписати тому, хто їх висловив, бо вони в певному сенсі $\epsilon$ проявом «колективного розуму» такої спільноти. Викладачі, які підвищують кваліфікацію у НКЦ «Педагогічна майстерність викладача вищої школи» ОНПУ відвідують заняття кожен тиждень протягом навчального року та проводять інтерактивні міні-заняття 3 педагогічної майстерності для колег на основі практичних навичок організації педагогічної дії та ціннісного досвіду, продовжуючи втілювати у життя ідеї І. А. Зязюна про те, що гуманізоване суспільство вимагає здатності особи обирати цінності й правила поведінки, що не ламають звичні суспільні норми, а збагачують культурно-ціннісний досвід людства.

Зауважимо, що організація курсів підвищення кваліфікації «Педагогічна майстерність викладача вищої школи» носить також й суспільно значущий характер в інтересах збереження інтелектуальнокультурного потенціалу для майбутнього України. Адже, культура народу і держави є найважливішим із показників його прогресу завдяки особливій місії педагога, який творить найбільшу, найвагомішу, найнеобхіднішу цінність - Людину. Саме педагогічна майстерність (комплекс властивостей особистості, що забезпечує самоорганізацію високого рівня професійної діяльності на рефлексивній основі [16, С. 25]) визначає ефективність поступу сучасної української освіти, за рахунок "опочуттєвлення", “олюднення” професійних знань і вмінь саме завдяки діям Педагога.

Висновки 3 даного дослідження та перспективи подальших розвідок. В умовах модернізації вищої освіти в Україні пріоритетна увага має надаватися під- 
ТЕОРЕТИКО-МЕТОДОЛОГІЧНІ ТА ПРАКСЕОЛОГІЧНІ АСПЕКТИ ФОРМУВАННЯ ТА РОЗВИТКУ ТЕОРІЇ ЛІДЕРСТВА В ПАРАДИГМІ СУЧАСНОГО УПРАВЛІННЯ

готовці нової генерації науковопедагогічних та інженерно-педагогічних кадрів - національної еліти, яка здатна оволодіти новою освітньо-світоглядною парадигмою національно-державного творення, гуманного піднесення самоцільної особистості майбутнього фахівця. Отже, природним чином у взаємній відповідності мають гармонічно поєднуватися: дескриптивність нелінійного теоретичного знання про самоорганізацю, нелінійність істини як процесу в епістемологічних засадах постнекласичної науки, дескриптивність епістемологічних моделей сучасного наукового дискурсу, комунікативний

\section{Список літератури}

1. Бендас, Т. В. (2009) Психология лидерства. Учебное пособие. СПб.: Питер,. 448 с.

2. Буданов, В. Г. (2007) Методология синергетики в постнеклассической науке и в образовании. М.: ЛКИ, 232 с.

3. Добронравова, И. С. (2014) Практична філософія постнекласичної науки про наукову істину та людську свободу. Філософія освіти. № 2. С. 224-234.

4. Добронравова, І.С. (2017) Дескриптивність нелінійного теоретичного знання та самоорганізація нелінійної науки. Людина в складному світі. За ред. Н. В. Кочубей, М. О. Нестерової; вступне слово В. П. Адрущенка. Суми: Університетська книга, С. 179-192.

5. Ершова-Бабенко,И. В.(2015) Сборник лекций по психосинергетике. Одесса: Одесский филиал Украинского синергетического общества, 270 с.

6. Ершова-Бабенко, И.В.(2005)

Социальная среда в свете изменений в науке: конец XX - начало XXI ст. Психосинергетиские стратегии человеческой деятельности (концептуальная модель) : монография. Винница: NOVA KNYHA, 360 с.

7. Зязюн, І. А. (2003) Освітні парадигми в контексті філософських ідей. Професійна освіта: педагогіка і психологія. Українсько-польський журнал. За ред. I. Зязюна, Т. Левовицького, Н. Ничкало, вимір самоорганізації постнекласичного знання та постнекласичної науки. Що і $€$ свідченням зростання методологічної свідомості постнекласичної нелінійної науки, коли філософські засади методів наукового дослідження відповідають його предмету. Відтак, спираючись на конструктивний досвід української наукової школи І.А. Зязюна, стало можливим означити загальні теоретико-методологічні витоки і змістові лінії постнекласичного періоду методологічного виміру єдності нелінійного синтезу знань в аспекті розвитку теорій лідерства.

I. Вільш. Ченстохова Київ: Видавництво Вищої Педагогічної школи у Ченстохові,. Вип. № 5. С. 213-226.

8. Зязюн, І. А. (2008) Філософія педагогічної дії : монографія К.: [б. в.]; Черкаси: ЧНУ ім. Б. Хмельницького, 608 с.

9. Князева, Е.Н.(2012) Нелинейно-динамический подход в эпистемологии. Эволюиионная эпистемология. М.: СПб.: Центр гуманитарных инициатив, 704 с.

10. Кремень, В.Г. (2018) Філософсько-педагогічна спадщина академіка Івана Зязюна в контексті модернізації освіти. Філософія $i$ психологія педагогічної дії. Естетика і етика педагогічної дії. Вип. 17, C. 9-19.

11. Кримський, С. Б. (2008) Запити філософських смислів. Під сигнатурою Coфiï. К.: Вид. дім «Києво-Могилянська академія», С. 441-718.

12. Любовинкина, Е. (2017) Лидерство [Електронний ресурс] Mental Skills. Режим доступу: http://www.mentalskills.ru/dict/liderstvo

13. Мамардашвили, М. К. (1990) Наука и культура. Как я понимаю философию. М.: Прогресс, С. 337-356.

14. Нестерова, М. А. (2015) Когнитивистика: истоки, вызовы, перспективы. Сумы: Университетская книга, 334 с.

15. Пайтген, Х. О., \& Рихтер, П. Х. (1993) Красота фракталов: Образы комплексных динамических систем. М.: Мир, $176 \mathrm{c}$. 
16. Зязюн, I. А. (2008) Педагогічна майстерність : підручник. 3-є вид., допов. і переробл. К. : Богданова А. М, 376 с.

17. Семенова, А. В. (2014) Емоційне усвідомлення як конструкт оцінювання динаміки розвитку педагогічної майстерності викладачів вищих технічних навчальних закладів: психопедагогічний підхід. Теорія $i$ практика управління сочіальними системами. Щоквартальний науково-практичний журнал. Х.: НТУ “ХПІ”, № 4, С. 58-68.

18. Семенова, А. В. \& Зуєва, Л. С. (2017) Соціальний контекст психологопедагогічної підготовки професійних суддів у системі суддівської освіти України і Канади в аспекті інтегральної теорії лідерства. Лідер. Еліта. Суспільство. Щоквартальний науково-практичний журнал. X.: НТУ „ХПІ”, № 1, С. 109-123.

19. Семенова, А. В. (2017) Психопедагогічний супровід ефективного лідера XXI століття: синергетичний підхід. Science Rise: Pedagogical Education. №7 (15), C. 30-36.

20. Семенова, А. В. (2016) Ціннісний вимір досвіду суб'єктів педагогічної дії: монографія Одеса : Бондаренко М. О., $436 \mathrm{c}$.

21. Сергеєва, Л. М., Кондратьєва, В. П., \& Хромей, М. Я. (2015) Лідерство: навч. посібн. За наук. ред. Л. М. Сергеєвої. Івано-Франківськ. «Лілея-НВ», 296 с.

22. Chemers Martin.

Lawrence Erlbaum Associates, Psychology, $200 \mathrm{p}$.

23. Donald Markwell. (2013) Instincts to Lead: On Leadership, Peace, and Education, Connor Court: Australia, 500 p.

\section{References}

1. Bendas, T. V. (2009). Psihologija liderstva. [ The psychology of leadership] Uchebnoe posobie. SPb.: Piter. 448 s.[ in Russian ].

2. Budanov,V.G.(2007) Metodologija sinergetiki $v$ postneklassicheskoj nauke $i v$ obrazovanii. [ The methodology of synergetics in post-non-classical science and in education. ] M.: LKI. 232 s. [ in Russian ].
3. Dobronravova, Y. S. (2014) Praktychna filosofija postneklasychnoji nauky pro naukovu istynu ta ljudsjku svobodu. [ Practical philosophy of the postclassical science of scientific truth and human freedom.] Filosofija osvity. № 2. S. 224-234. [ in Ukrainian ].

4. Dobronravova, Iryna. (2017) Deskryptyvnistj nelinijnogho teoretychnogho znannja ta samoorghanizacija nelinijnoji nauky. [ Descriptivism of nonlinear theoretical knowledge and self-organization of nonlinear science] Ljudyna $\mathrm{v}$ skladnomu sviti. Sumy: Universytetsjka knygha. S.179192. [ in Ukrainian ].

5. Ershova-Babenko, I. V. (2015) Sbornik lekcij po psihosinergetike. [Collection of lectures on psychosynergetics] Odessa: Odesskij filial Ukrainskogo sinergeticheskogo obshhestva. [ in Russian ].

6. Ershova-Babenko, I. V. (2005) Social'naja sreda $v$ svete izmenenij $v$ nauke : konec XX - nachalo XXI st. [ Social environment in the light of changes in science: the end of the XX - beginning of the XXI century] Psihosinergetiskie strategii chelovecheskoj dejatel'nosti (konceptual'naja model') : monografija. Vinnica: NOVA KNYHA. 360 s.[ in Russian ].

7. Zjazjun, I. A. (2003). Osvitni paradyghmy $v$ konteksti filosofsjkykh idej. [Educational Paradigms in the Context of Philosophical Ideas] "Profesijna osvita: pedaghoghika i psykhologhija". Ukrajinsjkopoljsjkyj zhurnal za red. I. Zjazjuna, T. Levovycjkogho, N. Nychkalo, I. Viljsh. Chenstokhova - K.: Vydavnyctvo Vyshhoji Pedaghoghichnoji shkoly u Chenstokhovi, Vol. 5. pp. 213-226. [ in Ukrainian ].

8. Zjazjun, I. A. (2008) Filosofija pedaghoghichnoji diji: monoghrafija. [Philosophy of pedagogical action: monograph] K.: b. v.; Cherkasy : ChNU im. B. Khmeljnycjkogho. 608 s.[ in Ukrainian ].

9. Knjazeva, E. N. (2012) Nelinejnodinamicheskij podhod $v$ jepistemologii. [ Nonlinear Dynamic Approach to Epistemology] Jevoljucionnaja jepiste- 
mologija. $\mathrm{SPb} .:$ Centr gumanitarnyh iniciativ. 704 s. [ in Russian ].

10. Kremenj, Vasylj. (2018) Filosofsjko-pedaghoghichna spadshhyna akademika Ivana Zjazjuna v konteksti modernizaciji osvity. [ Academician Ivan Zyazun's Philosophical and Pedagogical Heritage in the Context of Modernization of Education] Filosofija i psykhologhija pedaghoghichnoji diji. Estetyka i etyka pedaghoghichnoji diji. Vyp. 17 S. 9-19. [ in Ukrainian ].

11. Krymsjkyj, S. B. (2008) Zapyty filosofsjkykh smysliv. [ Requests for philosophical meanings] Pid syghnaturoju Sofiji. K.: Vyd. dim «Kyjevo-Moghyljansjka akademija». S. 441-718. [ in Ukrainian ].

12. Ljubovinkina, E. (2017) Liderstvo [ Leadership] [Elektronnij resurs] Mental Skills. Rezhim dostupu do resursu: http://www.mental-skills.ru/dict/liderstvo. [in Russian ].

13. Mamardashvili, M. K. (1990) Nauka i kul'tura. [ Science and Culture] Kak ja ponimaju filosofiju. M.: Progress. S. 337356. [ in Russian ].

14. Nesterova, M. A. (2015) Kognitivistika: istoki, vyzovy, perspektivy. [Cognitivistics: origins, challenges, prospects] Sumy : Universitetskaja kniga. 334 s. [ in Russian ].

15. Pajtgen, H.-O. (1993) Krasota fraktalov : Obrazy kompleksnyh dinamicheskih sistem [ The beauty of fractals: Images of complex dynamic systems] M. : Mir. 176 s. [ in Russian ].

16. Zjazjun, I. A. (2008) Pedaghoghichna majsternistj : pidruchnyk. [Pedagogical skills: a textbook] K. : Boghdanova A. M. 376 s. [ in Ukrainian ].

17. Semenova, A. V. (2014). Emocijne usvidomlennja jak konstrukt ocinjuvannja dynamiky rozvytku pedaghoghichnoji majsternosti vykladachiv vyshhykh tekhnichnykh navchaljnykh zakladiv: psykhopedaghoghichnyj pidkhid. [Emotional awareness as a construct of eval- uation of the dynamics of pedagogical skills development of teachers of higher technical educational institutions: psycho-pedagogical approach ] "Teorija i praktyka upravlinnja socialjnymy systemamy” Kharkiv: NTU „KhPI”, 2014. Vol. 4. pp. 58-68. [ in Ukrainian].

18. Semenova, A. V. Zujeva, L. Je. (2017) Socialjnyj kontekst psykhologhopedaghoghichnoji pidghotovky profesijnykh suddiv u systemi suddivsjkoji osvity Ukrajiny $i$ Kanady $v$ aspekti integhraljnoji teoriji liderstva. [The social context of psychological and pedagogical training of professional judges in the system of judicial education of Ukraine and Canada in the aspect of integral theory of leadership ] «Lider. Elita. Suspiljstvo» Shhokvartaljnyj naukovopraktychnyj zhurnal. Kh.: NTU „KhPI” Vol. 1 pp. 109-123. [ in Ukrainian ].

19. Semenova, A. V. Psykhopedaghoghichnyj suprovid efektyvnogho lidera XXI stolittja: synerghetychnyj pidkhid. [ Psycho-pedagogical support of an effective leader of the XXI century: a synergistic approach ] ScienceRise: Pedagogical Education. Vol. 7 (15). pp. 30-36. [ in Ukrainian ].

20. Semenova, Alla (2016). Cinnisnyj vymir dosvidu sub'jektiv pedaghoghichnoji diji : monoghrafija. [Valuable dimension of the experience of subjects of pedagogical action: monograph ] Odesa : Bondarenko M. O. 436 s. [ in Ukrainian ].

21. Serghejeva, L. M. (2015). Liderstvo : navch. posibn. [Leadership: Teacher. manual ] Ivano-Frankivsjk. «LilejaNV». 296 s. [ in Ukrainian ].

22. Chemers, Martin. (1997). Lawrence Erlbaum Associates. Psychology. 200 p.

23. Donald Markwell. (2013). Instincts to Lead: On Leadership, Peace, and Education. Connor Court: Australia. 500 p.

Стаття надійшла до редколегіï: 15.06.2018 